\title{
BIOTECHNOLOGY OF NEWLY CREATED BACTERIAL COMPOSITION FOR SILOING BASED ON LACTIC ACID BACTERIA
}

\author{
S.G. Danylenko', O.V. Naumenko', A.S. Onishchenko ${ }^{1}$, \\ S M. Teterina ${ }^{2}$, M.O. Khonkiv ${ }^{1}$, S.O. Skrotskyi ${ }^{3}$ \\ ${ }^{1}$ Institute of Food Resources of NAAS of Ukraine, \\ 4 A Eugene Sverstyuka Str., Kyiv, 02000, Ukraine \\ ${ }^{2}$ National University of Food Technologies, \\ 68 Vladimirskaya Str., Kyiv, 01601, Ukraine \\ ${ }^{3}$ Zabolotny Institute of Microbiology and Virology, NAS of Ukraine, \\ 154 Acad. Zabolotny Str., Kyiv, 03143, Ukraine \\ e-mail:svet1973@gmail.com
}

\begin{abstract}
Peculiarities of high-quality silage production are the use of biological products based on lactic acid bacteria. The composition of such starters varies greatly according to the use of bacterial cultures, so among the starters available on the market, the range of their effectiveness is also different. It is very common to use a one-sided approach to the choice of bacterial components, which in combination with imperfect production technology have low preservative activity. The study of combined preparations, which combine homo- and heterofermentative types of lactic acid fermentation, allows to stabilize the preservative properties throughout the ensiling time, and increase the aerobic stability of the silage after access of oxygen. Aim. Development of biotechnology of bacterial preparation for corn ensiling, optimization of cultivation conditions of newly created bacterial composition, and selection of cryoprotectants for its lyophilization. Methods. The combined preparation was created on the basis of heterofermentative strain Lactobacillus buchneri 3806 combining it in two- and three-strain compositions with other representatives of lactic acid bacteria, which are characterized by obligate homofermentative and facultative heterofermentative types of metabolism. Optimization of the environment and technological parameters was carried out using a central-compositional plan, further statistical analysis of the obtained data and determination of optimal values of input parameters according to the created mathematical model of optical density response. The effectiveness of the selected protective media was tested for the survival of bacteria after lyophilization. Results. The most effective bacterial composition was found during experiments: L. buchneri 3806, Enterococcus faecium C-8-12, L. plantarum 3216. The effectiveness of the obtained composition was tested by laboratory silage of corn. Tests of the drug based on the selected bacterial composition showed an improvement in the chemical composition of the silage compared to the untreated control and treated only with monoculture L. buchneri 3806, namely: there was a decrease in dry matter loss by $2.21 \%$ and $2.04 \%, 22$ due to the increase of lactic acid content, and increase of aerobic stability of silage - 341 h against $57 \mathrm{~h}$ of the control sample, and $313 \mathrm{~h}$ in case of using monoculture. For the obtained bacterial composition, the culture medium of the following composition was optimized: base (hydrolyzed milk with the addition of the following components: monosubstituted potassium phosphate - $2 \mathrm{~g} / \mathrm{L} ; 5$-aqueous manganese sulfate - $0.05 \mathrm{~g} / \mathrm{L} ; 7$-aqueous magnesium sulfate $0.2 \mathrm{~g} / \mathrm{L}$; twin- $80-1.0 \mathrm{~g} / \mathrm{L}$ ); glucose $-19.7 \mathrm{~g} / \mathrm{L}$; yeast extract - $7.8 \mathrm{~g} / \mathrm{L}$; corn extract $-23.6 \mathrm{~g} / \mathrm{L}$; peptone $9.1 \mathrm{~g} / \mathrm{L}$; sodium citrate $-6.6 \mathrm{~g} / \mathrm{L}$; sodium acetate $-3,4 \mathrm{~g} / \mathrm{L}$. Cultivation of the bacterial composition on an optimized medium made it possible to obtain the maximum biomass yield, at which the optical density was 2.01 units, which is almost twice as much as the value obtained by culturing the same composition in MRS medium. The optimal technological parameters of culturing the bacterial composition were established, namely the best growth was observed at a temperature of $36.4 \pm 0.4{ }^{\circ} \mathrm{C}$ with constant maintenance of the pH value in the culture medium at the level of $6.5 \pm 0.1$ units. In addition, the optimal composition of the protective medium containing sodium citrate, sucrose and agar was selected, and ensures the survival rate of lactic acid bacteria $98.4 \%$ after lyophilization. Conclusions. The newly formed bacterial composition can be used for the production of preparations for corn silage, and tested on other raw materials,
\end{abstract}


in particular on some perennial legumes (alfalfa, clover), and the conditions of its production can be used to scale the technology.

Keywords: silage, lactic acid bacteria, biopreparation, optimization, central-composition plan, nutrient medium, technological parameters, protective environment.

Modern biological additives for ensiling sometimes have limited effectiveness, because most of them were created without taking into account the target plant raw materials, conditions for cultivation in the technology silage additives and for obtaining their final form. This is due to the lack of information on modern experimental studies on key aspects of biotechnology of silage preparations. And most of the available work is devoted to the research of the effectiveness of application or technology of development only bacterial monopreparations [1-3]. Whereas the influence of multi-component bacterial preparations provides a more holistic achievement of optimal critical values for silage, such as aerobic stability, $\mathrm{pH}$ of silo, organic acid ratio, content crude protein and total dry matter [4]. However, due to the different requirements of joint cultivation of several bacterial strains of lactic acid bacteria (LAB), it is necessary to choose the optimal parameters of the process (active acidity, temperature) and composition of the nutrient medium.

High-quality biological silage additives obtaining directly depends on the organization of the process of cultivation of microorganisms (medium, temperature and $\mathrm{pH}$ ) and post-fermentation biomass processing. The most effective approach to optimization is the use of mathematical methods of experimental design (DOE). A quick result is achieved by combining the above methods with statistical analysis, which significantly reduces the time and material resources for research. This is especially important when using combined additives, in which bacterial cultures differ from each other in the needs of growth factors and resistance to environmental conditions. Among modern methods, such as, response surface methodology (RSM), artificial neural networks and genetic algorithms are often used for this purpose $[5,6]$. The aim of the work was to develop the biotechnology of bacterial additives for corn silage with the involvement of obligate heterofermentative, facultative heterofermentative and obligate homofermentative LAB.

At the moment, a large number of preparations for silage making are presented on the market, the said preparations being widely used domestically as well as abroad [7-9].

Doji et al. showed [10] that in silage without a starter culture the number of some species of micromycetes was significantly lower than in the silage with the introduction of L. rhamnosus RC007 strain.

Corsetti et al. [11] recorded a significant antifungal effect of $L$. sanfrancisco CBI bacterial strain, which inhibited the growth of micromycetes.

The use of preparations based only on homofermentative strains of LAB in the preserving of corn can cause undesirable consequences [12].

Homofermentative LAB have often been used to improve silage quality by accelerating the fermentation of sugar into lactic acid followed by a rapid drop in $\mathrm{pH}$. The bacteria that belong to this group are morphologically different. These are cocci belonging to the genera Lactococcus, Enterococcus, Streptococcus and Pediococcus, as well as long or short rods from the genus $\mathrm{Lac}$ tobacillus. But, there is a limited possibility of preserving nutrients, which depends only on the $\mathrm{pH}$ value, which is lowered with the help of homofermentative bacteria, since the lactic acid obtained by them can be easily used by yeasts and molds when exposed to oxygen [13].

When ensiling plant materials, the use of heterofermentative bacteria L. buchneri, which prevents aerobic spoilage, is of increasing interest. Driehuis F, et al. showed that the introduction of only L. buchneri strains into the silage leads to an increase in the content of acetic acid in the forage and losses during ensiling [14]. Acetic acid has good antifungal properties [15], but its excess into the silage impairs the palatability. Among the variety of heterofermentative LAB, $L$. brevis cultures are widely used [16]. Studies by Inglis GD et al. showed [17] that acetic acid is formed by $L$. brevis bacteria in the initial phase of silage fermentation, and L. buchneri convert lactic acid into acetic acid at later stages of fermentation, ultimately changing the physical and chemical characteristics of the silage.

The simultaneous application of homo-enzymatic and hetero-enzymatic LAB is effective to improve the fermentation characteristics and 
aerobic stability of corn silage. This leads to the possibility of the formation of lactic acid at high $\mathrm{pH}$ values of forage plants, a more rapid decrease in acidity, which is a favorable condition for the development and activity of homofermentative L. plantarum [18]. In addition, a rapid drop in $\mathrm{pH}$ of the silage results in better retention of nutrients such as water-soluble carbohydrates, and also contributes to lower ammonia content in the feed. After a decrease in acidity and the final formation of lactic acid, L. buchneri begins to produce acetic acid from lactic acid and thereby increase the aerobic stability of the silage. The effectiveness of LAB for preserving is based on their competitive ability towards epiphytic microflora in feed. To carry out the desired fermentation in bacterial starter cultures, a twofold increase in the amount of introduced LAB over the epiphytic microflora is required [19]. From an economic point of view, the introduction of compositions with homo- and heteroenzymatic LAB is justified to be expedient.

In this regard, the development and testing of new preparations, the development of methods for their use is an important area of research.

Materials and methods. Two strains of Lactobacillus buchneri 3806 and L. plantarum 3216 isolated from corn silage, 2 strains of Enterococcus faecium C-8-12, E. faecium C-6-6 isolated from rabbit feces, and 3 strains of L. acidophilus 7074, L. casei 3300, L. brevis 3432, from culture collections, stored in the Department of Biotechnology of the Institute of Food Resources of NAAS of Ukraine were used as study objects. Cultures of LAB were maintained on MRS medium at a temperature of $(4 \pm 2){ }^{\circ} \mathrm{C}$.

Efficiency of application of combined bacterial additives on corn silage. Silage in the laboratory was performed as follows: corn was placed in glass jars, carefully compacted and sealed. The dose of culture L. buchneri 3806 and the finished liquid preparation was $100 \mathrm{~cm}^{3}$ per 1 ton of green mass. The final concentration of microorganisms in the plant material was $5.2-6.3 \cdot 10^{5} \mathrm{CFU} / \mathrm{cm}^{3}$, D1 - the sample was processed with a suspension of the bacterial composition of L. buchneri 3806, E. faecium C-8-12, L. plantarum 3216; D2 - with monoculture L. buchneri 3806; control (C) without processing. On the basis of these strains, 9 starter cultures were compiled experimentally. Each starter was examined to determine their suitability for fermenting plant raw materials. Microorganisms for the production of complex starter cultures were prepared separately from each other according to the classical technology with their subsequent combination in different ratios. To establish the optimal ratio of the strains, the optical density and the change in the $\mathrm{pH}$ of the medium during cultivation were determined.

The duration of the experiment is 4 weeks. Determined the chemical composition (dry matter, carbohydrates, organic acids, crude protein), active acidity, and aerobic stability of the finished silage.

The dry matter content was determined by the difference in the weight of the silage before and after drying at $(105 \pm 2){ }^{\circ} \mathrm{C}$ for $6 \mathrm{~h}$ [20]. The crude protein content was determined by photometric method. The method is based on the decomposition of organic substances of the test sample with concentrated sulfuric acid with the formation of ammonium salts and subsequent photometric determination of nitrogen in the form of colored indophenolic compound formed in alkaline medium by interaction with sodium salicylate and hypochlorite and has a maximum light absorption [21]. Water-soluble carbohydrates were determined photocolorimetrically with an anthrone reagent [22]. The mass fraction of organic acids was determined by the Lepper-Flig method [23]. The active acidity of the aqueous silo extract was determined using a pH-meter [24].

Aerobic stability of the silage was determined by the time that elapses from the moment of opening the silage (contact with oxygen) to increase the temperature of the silage by $2^{\circ} \mathrm{C}$ [25].

Optimization of biomass accumulation conditions. As the basis of the medium used hydrolyzed milk with the addition of salts: monopotassium phosphate $-2 \mathrm{~g} / \mathrm{L}$; 5 -aqueous manganese sulfate $0.05 \mathrm{~g} / \mathrm{L}$; magnesium sulfate 7 -water $-0.2 \mathrm{~g} / \mathrm{L}$ and twin- $80-1.0 \mathrm{mg} / \mathrm{L}$.

To the experimental media were added six components in the following ranges of concentrations: Glucose, corn extract in the amount of $10-20 \mathrm{~g} / \mathrm{L}$, casein peptone $-5-10 \mathrm{~g} / \mathrm{L}$, yeast extract $-3-7 \mathrm{~g} / \mathrm{L}$, sodium acetate, $2-4 \mathrm{~g} / \mathrm{L}$ and sodium citrate $-3-7 \mathrm{~g} / \mathrm{L}$. Control - MRS medium.

As inoculum used daily cultures included in the newly created bacterial composition with a titer of not less than $1.0 \cdot 10^{8} \mathrm{CFU} / \mathrm{cm}^{3}$ which were made in an amount of $6 \%$ by volume of the medium at a ratio of $1: 1: 1$. The initial value of the optical density of the bacterial suspension was 0.1 units (at a wavelength of $590 \mathrm{~nm}$ ).

To set up a study to find the optimal environment, mathematical methodology of experimental design (DOE) was used. To reduce the number of experiments for 6 factors, a central 
composite design (CCD) was chosen. The criterion of optimality was chosen optical density of the culture fluid, which characterizes the increase in biomass. After a series of measurements of the optical density before inoculation, due to the addition of colored components of the medium in different concentrations (corn and yeast extracts), corrections were made to the value at the end of cultivation. Cultivation of microorganisms was carried out in a periodic mode with stabilization of the $\mathrm{pH}$ of the culture fluid in the range of 6.0-6.5 units for 14 hours at a temperature of $(36 \pm 1)^{\circ} \mathrm{C}$. The level of biomass accumulation by optical density was determined by the spectrophotometric method on a Unico S 2100+ spectrophotometer (at a wavelength of $590 \mathrm{~nm}$ ).

The study of the influence of technological parameters on the growth properties of LAB was carried out according to a similar design of CCD. Cultivation was performed on a medium of pre-optimized composition. Determination of the temperature optimum was performed in the range of $33-38{ }^{\circ} \mathrm{C}$, maintaining the required temperature in the thermostat during the entire cultivation. Whereas, to determine the optimal $\mathrm{pH}$, a range of values was chosen 6.0-7.0 units. Determination of active acidity in the culture fluid was performed potentiometrically. The acidity value was maintained at the same level by adding $25 \%$ aqueous ammonia solution.

Experiment design and data processing were performed using the software for statistical analysis STATISTICA 12. During the processing of the results, the coefficients of the regression polynomial equation and their variance were calculated. The statistical significance of the results was verified by Fisher's exact test. Values of experimental data, as well as regression coefficients were considered statistically significant if $\mathrm{p} \leq 0.05$.

Selection of a protective medium for lyophilization. 4 variants of protective medium were used. PM 1: skimmed milk powder $-10 \mathrm{~g}$, sodium cit- rate $-0.2 \mathrm{~g}$, sucrose $-1.0 \mathrm{~g}$, magnesium sulfate $0.05 \mathrm{~g}$, distilled water - up to $100 \mathrm{~cm}^{3}$. PM 2: skimmed milk powder $-3 \mathrm{~g}$, sucrose $-15 \mathrm{~g}$, gelatin $-5 \mathrm{~g}$, distilled water - up to $100 \mathrm{~cm}^{3}$. PM 3: sodium citrate $-5 \mathrm{~g}$, sucrose $-25 \mathrm{~g}$, agar $-0.1 \mathrm{~g}$, distilled water - up to $100 \mathrm{~cm}^{3}$. PM 4: skimmed milk powder $-14 \mathrm{~g}$, inositol $-10 \mathrm{~g}$, agar $-0.1 \mathrm{~g}$, distilled water - up to $100 \mathrm{~cm}^{3}$. Control - distilled water. To assess the effectiveness of the protective medium, the degree of bacterial survival was determined by the ratio of the number of cells before and after lyophilization in $1 \mathrm{~cm}^{3}$ the bacterial suspension.

Bacterial composition was grown for 14 hours at a temperature of $37{ }^{\circ} \mathrm{C}$, then mixed with a protective medium in a ratio of $1: 1$, the resulting suspension was poured into vials of $2 \mathrm{~cm}^{3}$. It was then placed in a drying chamber. The process was carried out in a freeze-dryer TG-15 under the following technological regime: initial temperature minus $(40 \pm 1){ }^{\circ} \mathrm{C}$, final - plus $(30 \pm 2){ }^{\circ} \mathrm{C}$, residual pressure - not more than $6.65 \mathrm{~Pa}\left(0.679 \mathrm{kgf} / \mathrm{m}^{2}\right)$. Drying time $-30-34$ hours.

After drying, the powder containing bacterial biomass with residues of the components of the media was reduced with distilled water to the original volume.

Results. Based on previous studies, 9 two- and three-strain compositions were created from the promising strains, which were combined taking into account different types of metabolism of LAB, namely:

- obligate homo- and heterofermentative bacteria: L. buchneri $3806+$ L. acidophilus $7074 /$ L. casei 3300 / E. faecium C-8-12 / E. faecium C-66 ;

- 2 species of obligate heterofermentative bacteria: L. buchneri $3806+$ L. brevis 3432 ;

- obligate heterofermentative and facultatively heterofermentative bacteria: L. buchneri $3806+$ L. plantarum 3216 ;

\section{Table 1}

Variants of combinations of bacterial composition

\begin{tabular}{|l|c|c|c|c|c|c|c|c|c|}
\hline \multirow{2}{*}{ Strain } & \multicolumn{9}{|c|}{ Compositions } \\
\cline { 2 - 11 } & 1 & 2 & 3 & 4 & 5 & 6 & 7 & 8 & 9 \\
\hline 3806 & + & + & + & + & + & + & + & + & + \\
\hline 7074 & + & & & & & & + & & \\
\hline 3300 & & + & & & & & & & \\
\hline 3432 & & & + & & & & & & + \\
\hline 3216 & & & & + & & & + & + & + \\
\hline C-6-6 & & & & & + & & & + & + \\
\hline C-8-12 & & & & & & + & & & + \\
\hline
\end{tabular}


- obligate heterofermentative, facultatively heterofermentative and obligate homofermentative bacteria: L. buchneri $3806+$ L. plantarum $3216+$ L. acidophilus 7074 / L. casei 3300 / E. faecium C-8-12 / E. faecium C-6-6.

Variants of combinations of bacterial composition are given in Table 1.

For a more detailed assessment, we calculated a constant cell division rate for cell concentration values in the time range from 4 to 12 hours. The obtained values are given in Table 2.

From Table 2 it is seen that according to the rate constants of cell division, variant 9 has the highest population growth rate. Approximate results have options 8 and 4, and the worst results belong to variant 3 .

In addition to the growth rate, to compare the bacterial compositions were also determined optical density and $\mathrm{pH}$ in the culture fluid after 14 hours of cultivation (Table 2).

The results of determining the optical density are naturally correlated with the results on the growth rate of the bacterial population in the compositions. Thus, variant 9 is accordingly characterized by the best compatibility of cultures, the highest level of biomass accumulation, a high rate of population growth of active cells and a decrease in the acidity of the environment without a sharp inhibition of the growth properties of cultures.

Based on these results, variant 9 of bacterial composition based on strains of L. buchneri 3806, E. faecium C-8-12 and L. plantarum 3216 was selected for further studies.

The effect of the newly created bacterial composition on the quality of corn silage. Composition based on strains of L. buchneri 3806, E. faecium C-8-12, L. plantarum 3216, as mentioned earlier, is represented by three types of lactic acid fermentation, which in this composition allows the use of different types of fermentation with high compatibility of the presented strains. Predicted in the silo, this composition is able to efficiently accumulate its biomass. In addition, the use of three types of lactic acid fermentation allows the accumulation of a wide range of antimicrobial metabolites, with both fungicidal and bactericidal activity [26].

The effectiveness of the newly formed bacterial composition was tested in a laboratory ensiling experiment using the newly formed composition (L. buchneri 3806, E. faecium C-8-12, L. plantarum 3216) (D1), monoculture of L. buchneri 3806 (D2), and control - without processing $(\mathrm{C})$.

Table 3 presents the quality indicators of corn silage obtained by simultaneous bookmarking with and without the use of leaven.

The aerobic stability of the silage is known to be one of its most important parameters, that is, the safety of nutrients and the safety of feed after opening the storage. A specially bred strain of the heteroenzymatic bacterium L. buchneri is capable of producing acetic acid, which ensures the stability of the feed when taken out of storage. Analyzing the data presented in Table 3, it can be noted that compared with the control and D2 in the case of the bacterial composition D1 there is a sharper decrease in $\mathrm{pH}$, which in turn is observed not only in terms of active acidity but also in total organic acids. In the experiment with the starter D2 significantly lower growth and acid-forming properties compared with D1. Aerobic stability of silage treated with D1 is maintained for about two weeks (341 hours), which is sufficient to prevent heating and spoilage of silage due to the development of aerobic microorganisms, while for D2 this figure is 28 hours lower.

\section{Table 2}

Values of optical density, pH after 14 hours of cultivation

\begin{tabular}{|l|c|c|c|c|}
\hline Variants & $\begin{array}{c}\text { Rate constants of } \\
\text { cell division } v, \mathrm{~h}^{-1}\end{array}$ & Optical density, $\mathrm{D}$ & $\mathrm{pH}$ & Strains $^{*}$ \\
\hline 1 & 0.394 & $0.80 \pm 0.03$ & $4.45 \pm 0.15$ & L.buc. $3806:$ L.a. 7074 \\
\hline 2 & 0.312 & $0.73 \pm 0.05$ & $4.49 \pm 0.18$ & L.buc. 3806: L.c. 3300 \\
\hline 3 & 0.209 & $0.68 \pm 0.03$ & $4.61 \pm 0.1$ & L.buc. 3806: L.br 3432 \\
\hline 4 & 0.500 & $0.84 \pm 0.02$ & $4.47 \pm 0.06$ & L.buc. 3806: L.p. 3216 \\
\hline 5 & 0.387 & $0.77 \pm 0.04$ & $4.41 \pm 0.14$ & L.buc. 3806 : E.f. C-6-6 \\
\hline 6 & 0.471 & $0.79 \pm 0.02$ & $4.40 \pm 0.05$ & L.buc. 3806 : E.f. C-8-12 \\
\hline 7 & 0.547 & $0.85 \pm 0.03$ & $4.38 \pm 0.08$ & L.buc. 3806: L.p. 3216: L.a. 7074 \\
\hline 8 & 0.538 & $1.06 \pm 0.05$ & $4.35 \pm 0.15$ & L.buc. 3806 : L.p. 3216: E.f. C-6-6 \\
\hline 9 & 0.558 & $1.08 \pm 0.05$ & $4.33 \pm 0.15$ & L.buc. 3806: L.p. 3216: E.f. C-8-12 \\
\hline
\end{tabular}

*L.buc. 3806 - L. buchneri 3806, L.p. 3216 - L. plantarum 3216, E.f. C-8-12 - E. faecium C-8-12, E.f. C-6-6 E. faecium C-6-6, L.a. 7074 - L. acidophilus 7074, L.c. 3300 - L. casei 3300, L.br. 3432 - L. brevis 3432. 
The presence of two homofermentative strains of E. faecium C-8-12 and L. plantarum 3216 was effective in terms of solving the problem of high $\mathrm{pH}$ silage, because at active acidity values of $4.22 \pm 0.03$, the activity of the undesired microbiota was significantly reduced. This leads to a significant increase in the level of dry matter retention, including dry protein and water-soluble carbohydrates. The absence of butyric acid, ethanol and ammonia indicates the suppression of the development of unwanted microbiota.

It is believed that a rapid drop in $\mathrm{pH}$ to close to 4.2 or less is sufficient to preserve the corn. This $\mathrm{pH}$ value was reached for sample D1. Involvement of L. plantarum and E. faecium strains significantly increased the rate of $\mathrm{pH}$ decrease compared to the control sample. These results are consistent with those of Saarisalo et al. [27].

Organoleptic characteristics of silage correlated with the results of chemical analysis. Thus, the smell of samples D1 and D2 had a pleasant fruity hue, the color was uniform, while the control was characterized by a sharp and unpleasant odor. The color for all samples was uniform yellow-brown.

Thus, these results prove the effectiveness of the preparation based on the selected bacterial composition in the process of ensiling corn. In addition to corn, this bacterial additive can be tested on other raw materials, such as some perennial legumes (alfalfa, clover), where there is a high probability of contamination of raw materials with yeast, fungi and putrefying bacteria.

Optimization of cultivation conditions. To optimize the culture medium, 6 components were selected, the changes of which could increase the level of bacterial biomass accumulation. As a carbon source, glucose was selected, which is part of the MRS medium and is the main carbohydrate of corn cell sap. As the main source of nitrogen nutrition, instead of meat extract, used concentrated corn extract. The range of concentrations of glucose and corn extract was chosen 10-20 g/L. To meet all the needs of LAB metabolism, among other sources of nitrogen nutrition and growth factors, the medium was supplemented with casein peptone in the concentration range - 5-10 g/L, and yeast extract $-3-7 \mathrm{~g} / \mathrm{L}$. In addition, sodium acetate and citrate were used in the concentration ranges of 2-4 g/L and 3-7 g/L, respectively. The growth of cell biomass was assessed by the optical density (D) of the culture fluid. To obtain information on the response of the optical density depending on the concentration of the components of the growth medium, a three-level central compositional plan of experiments was chosen. In the course of our research [26] the optimal concentrations of the components of nutrient medium were calculated, the theoretical optical density reaches the value of 2.08 units. To verify the theoretically obtained results, the bacterial composition was cultured for $14 \mathrm{~h}$ at $37{ }^{\circ} \mathrm{C}$. To the base medium was added components of the following composition, g/L: glucose -19.7 ; yeast extract -7.8 ; corn extract 23.6; casein peptone -9.1 ; sodium citrate -6.6 ; sodium acetate -3.4 .

As a result of verification, the value of the optical density for the three replicas of optimized medium was $2.01 \pm 0.01$, while for the MRS medium the value of the optical density was $1.08 \pm$ 0.02 [28].

Our results are consistent with the results Zielińska et al, where in study, the Plaquet-Burmese method was used to assess the effect of nutrient components before using the central composite plan, resulting in a biomass of L. rhamnosus PEN strain of $1.9 \mathrm{~g} / \mathrm{L}$ compared to this new hybrid methodology with concentration on MRS [4].

To optimize the $\mathrm{pH}$ and temperature, it was decided to choose the standard ranges of values of these parameters for lactobacilli and enterococci, 6-7 units, and $33-38{ }^{\circ} \mathrm{C}$, respectively. The research was conducted on the same principle as for the optimization of nutrient medium. To begin with, the levels of variable factors were set according to the central composite plan, after which the experimental values of the optical density response were set for 12 variants.

The coefficient of determination is determined for this model, the value of which is $\mathrm{R}^{2}=0.997$ indicates a fairly close approximation of the response criterion of optimality to its real value. That is why according to this model, the predicted values must correlate quite accurately with the experimental ones.

The obtained regression equation with the calculated coefficients has the following formula (1):

$$
\begin{gathered}
Y=-55,3360+2,0022 \cdot Z_{1}+6,4068 \cdot \\
\cdot Z_{2}-0,0275 \cdot Z_{1}{ }^{2}-0,4895 \cdot Z_{2}^{2}
\end{gathered}
$$

It is proved that the values of the optimal parameters are in the $\mathrm{pH}$ range of 6.4-6.6 units, for $\mathrm{pH}$, and a temperature of 36 to $37^{\circ} \mathrm{C}$, which is important given the high probability of minor fluctuations in the parameters during cultivation.

To establish the values of temperature and active acidity of the culture medium at which the optical density will have the maximum value, the 


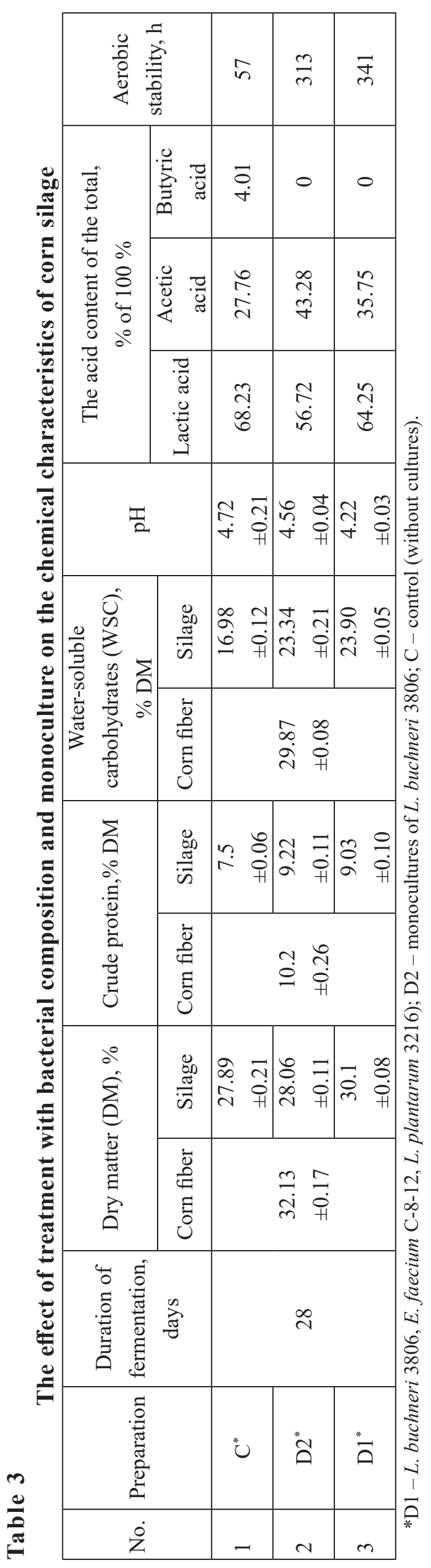


extremum of the response function was found at the maximum point. The results of calculations of the optimal values of the parameters are given in Table 4.

According to the calculated optimal parameters, the theoretical index of optical density reaches the value $\mathrm{D}=2.10$.

To verify the theoretically obtained results, the bacterial composition was cultured in a previously optimized medium [12] for $14 \mathrm{~h}$ at $36.4 \pm 0.4{ }^{\circ} \mathrm{C}$ and with constant maintenance of $\mathrm{pH}$ in the medium at $6.5 \pm 0.1$ units. For 3 replicas, the value of optical density was $2.07 \pm 0.01$ units. Compared with the standard values of the parameters used at the stage of optimization of the culture medium, the increase is insignificant -0.06 units, which in turn confirms the successfully selected parameters at the previous stage. Whereas outside these ranges of values, biomass growth much worse.
Selection of a protective medium for lyophilization. At the post-fermentation stage of biological product production, it is important to take into account the conditions of storage of accumulated biomass. At long storage of LAB in the closed volume their activity very quickly decreases. Therefore, a liquid preparation based on their biomass is effective in use for only a few days. In addition, given the different resistance to environmental conditions among the species that are part of the bacterial composition, there is interspecific competition in the population, resulting in the death of bacteria. Lyophilization is the most effective way to preserve bacterial cells. However, in the conditions of pre-freezing it is necessary to use a protective medium which includes substances with cryoprotective properties. The choice of protective medium is crucial in ensuring the preservation of cell integrity.

\section{Table 4}

Critical points of technological parameters
\begin{tabular}{|l|c|c|c|}
\hline \multirow{2}{*}{ Parameters } & \multicolumn{3}{|c|}{ The value of the parameter } \\
\cline { 2 - 4 } & Minimal & Maximum & Optimum \\
\hline Temperature $(\mathrm{t})$ & 31.5 & 38.5 & 36.4 \\
\hline Active acidity $(\mathrm{pH})$ & 5.8 & 7.2 & 6.5 \\
\hline \multicolumn{4}{|c|}{ Theoretical $\mathrm{D}_{\max }$} \\
\hline
\end{tabular}

In order to determine the best protective medium for drying the described three-strain bacterial composition (L. buchneri 3806, E. faecium C-8-12, L. plantarum 3216), several previously studied options were selected that ensure high survival of LAB [29]. The degree of cell survival during lyophilization was chosen as an evaluation criterion. The protective medium for lyophilization was chosen according to the results shown in Table 5.
As can be seen from Table 5, the highest degree of survival of bacterial cells is observed with the use of PM $3-98.4 \%$. Although other environments also showed correct results $(92.5-94.5 \%)$, that in comparison with control, proves efficiency of these cryoprotective substances use as a part of protective environments.

Thus, the developed biotechnology of the preparation for ensiling is recommended for largescale research in pilot fermenters.

\section{Table 5}

Influence of protective medium variant on the survival rate of cells

\begin{tabular}{|l|c|c|c|}
\hline $\begin{array}{l}\text { Variant of protective } \\
\text { medium }\end{array}$ & $\begin{array}{c}\mathrm{N}_{\text {cells }} \times 10^{-8} \text { before lyophilizathion, } \\
\mathrm{CFU} / \mathrm{cm}^{3}\end{array}$ & $\begin{array}{c}\mathrm{N}_{\text {cells }} \times 10^{-8} \text { after lyophilizathion, } \\
\mathrm{CFU} / \mathrm{cm}^{3}\end{array}$ & $\begin{array}{c}\text { Survival rate, } \\
\%\end{array}$ \\
\hline PM ${ }^{*}$ & $2.68 \pm 0.03$ & $2.53 \pm 0.03$ & 94.4 \\
\hline PM $2^{*}$ & $2.21 \pm 0.04$ & $2.11 \pm 0.06$ & 93.0 \\
\hline PM 3* & $2.43 \pm 0.02$ & $2.39 \pm 0.02$ & 98.4 \\
\hline PM 4* & $2.13 \pm 0.02$ & $1.97 \pm 0.04$ & 92.5 \\
\hline Control** & $2.16 \pm 0.07$ & $1.45 \pm 0.03$ & 67.1 \\
\hline
\end{tabular}

*Composition of protective media: PM 1. Skimmed milk powder $-10 \mathrm{~g}$, sodium citrate $-0.2 \mathrm{~g}$, sucrose $-1.0 \mathrm{~g}$, magnesium sulfate $-0.05 \mathrm{~g}$, distilled water - up to $100 \mathrm{~cm}^{3}$; PM 2. Skimmed milk powder $-3 \mathrm{~g}$, sucrose $-15 \mathrm{~g}$, gelatin $-5 \mathrm{~g}$, distilled water - up to $100 \mathrm{~cm}^{3}$; PM 3. Sodium citrate $-5 \mathrm{~g}$, sucrose $-25 \mathrm{~g}$, agar $-0.1 \mathrm{~g}$, distilled water - up to $100 \mathrm{~cm}^{3}$; PM 4. Skimmed milk powder $-14 \mathrm{~g}$, inositol $-10 \mathrm{~g}$, agar $-0.1 \mathrm{~g}$, distilled water - up to $100 \mathrm{~cm}^{3}$.

**Control - distilled water. 
Discussion. Therefore, an important stage in the development of biotechnology to inhibit epiphytic microflora in the silage mass is the development of new silage multicomponent starter cultures that combine the necessary properties of various types of LAB that begin the ensiling process and quickly reduce the $\mathrm{pH}$ level - Enterococcus and L. plantarum culture and stabilize the ensiling process $-L$. buchneri. The use of monobacterial preparations is less effective, since they cannot be equally active at all stages of acidification and allow unwanted microflora to degrade nutrients in the silage.

The results of this study show that the composition of L. buchneri 3806, E. faecium C-812 , L. plantarum 3216 is advantageous among other compositions, the use of which increases aerobic stability and contributes to the development in the domestic manufacturing of inoculants.

\section{Conclusions}

1. It was found that the use of the preparation based on biomass of strains Lactobacillus buchneri 3806, L. plantarum 3216 and Enterococcus faecium C-8-12 improves the chemical composition of silage compared to control and the use of only monoculture L. buchneri 3806 , namely: we observed reduction of dry matter losses by $2.21 \%$ and $2.04 \%$, respectively, lowering of $\mathrm{pH}$ level to 4.22 due to more intensive accumulation of lactic acid, which increases the aerobic stability of silage to $341 \mathrm{~h}$ compared to control $-57 \mathrm{~h}$, and the use of a single L. buchneri $-313 \mathrm{~h}$, respectively. Also, high activity of the newly created composition for the suppression of butyric acid bacteria and undesired microbiota was noted.

2. The composition of the components of the culture medium is selected, and their concentrations are optimized using the method of central composition plan and statistical analysis. Optimized liquid culture medium had the following composition, g/L: base - hydrolyzed with protosubtilin milk (with the addition of salts: monosubstituted potassium phosphate $-2 \mathrm{~g} / \mathrm{L}$; manganese sulfate 5 -aqueous $-0.05 \mathrm{~g} / \mathrm{L}$; magnesium sulfate 7 -aqueous $-0.2 \mathrm{~g} / \mathrm{L}$, twin- $80-1.0 \mathrm{~mL} / \mathrm{L}$ ), glucose -19.7 ; yeast extract -7.8 ; corn extract 23.6; casein peptone -9.1 ; sodium citrate -6.6 ; sodium acetate -3.4 . Cultivation on this medium provided almost 2 times higher optical density of the bacterial suspension than on MRS medium.

3. The optimal technological parameters of bacterial composition growth were established, namely the best growth was observed at a tem- perature of $36.4 \pm 0.4{ }^{\circ} \mathrm{C}$ and at constant maintenance of the $\mathrm{pH}$ value in the medium at the level of $6.5 \pm 0.1$ units. To maintain the viability of LAB cells for lyophilization conditions, a protective medium was selected that provides a survival rate of $98.4 \%$ and contains sodium citrate, sucrose and agar as cryoprotective substances.

\section{БІОТЕХНОЛОГІЯ НОВОСТВОРЕ- НОЇ БАКТЕРІАЛЬНОЇ КОМПОЗИ- ЦІї ДЛЯ СИЛОСУВАННЯ НА ОСНОВІ МОЛОЧНОКИСЛИХ БАКТЕРІЙ}

\section{С.Г. Даниленко А.С. Оніщенко ${ }^{1}$, С.М. Тетеріна ${ }^{2}$, М.О. Хоньків ${ }^{1}$, С.О. Скроцький}

${ }^{1}$ Інститут продовольчих ресурсів НААН України, вул. Свгена Сверстюка, 4А, Київ, 02000, Украӥна ${ }^{2}$ Начіональний університет харчових технологій, вул. Володимирська, 68, Київ, 01601, Україна

${ }^{3}$ Інститут мікробіології і вірусології ім. Д.К. Заболотного НАН Украӥни, вул. Академіка Заболотного, 154, Київ, 03143, Украӥна

\section{Резюме}

Особливостями виробництва високоякісного силосу $є$ використання біопрепаратів на основі молочнокислих бактерій. Склад таких препаратів сильно різниться за використанням бактеріальних культур, тому серед наявних препаратів на ринку діапазон їх ефективності також неоднаковий. Дуже часто спостерігається використання одностороннього підходу до вибору бактеріальних складових, що в поєднанні з недосконалою виробничою технологією мають низьку консервувальну активність. Дослідження комбінованих препаратів, в яких поєднуються гомоферментативне та гетероферментативне молочнокисле бродіння дозволяє стабілізувати консервувальні властивості протягом всього часу силосування і підвищити аеробну стабільність силосу після доступу кисню. Мета. Розробка біотехнології бактеріального препарату для силосування кукурудзи, оптимізація умов культивування новоствореної бактеріальної композиції та вибір кріопротекторів для її ліофілізації. Методи. Комбінований препарат створювали на основі облігатно гетероферментативного штаму Lactobacillus buchneri 3806, поєднуючи його в дво- та трьохштамові композиції з іншими представниками молочнокислих бактерій, яким властиві облігатно гомоферментативний та фа- 
культативно гетероферментативий шляхи зброджування вуглеводів. Оптимізацію середовища та технологічних параметрів здійснювали з використанням центрально-композиційного плану, подальшим статистичним аналізом одержаних даних та визначенням оптимальних значень вхідних параметрів за створеною математичною моделлю відгуку оптичної густини. Ефективність обраних захисних середовищ перевіряли за ступенем виживання бактерій після ліофілізації. Результати. В ході проведених експериментів було встановлено найбільш ефективну бактеріальну композицію, яка мала наступний склад: L. buchneri 3806, Enterococcus faecium C-8-12, L. plantarum 3216. Ефективність отриманої композиції було перевірено шляхом лабораторного силосування кукурудзи. Випробування препарату на основі обраної бактеріальної композиції показало покращення хімічного складу силосу порівняно з необробленим контрольним та обробленим лише монокультурою L. buchneri 3806, а саме: було відмічено зменшення втрат сухих речовин на $2,21 \%$ та 2,04\% відповідно, зниження рН силосу до 4,22 за рахунок збільшення вмісту молочної кислоти та підвищення аеробної стійкості силосу - 341 год проти 57 год контрольного зразка та 313 год у разі використання монокультури. Для одержаної бактеріальної композиції було оптимізовано поживне середовище наступного складу: основа (гідролізоване молоко з додаванням таких компонентів: калій фосфорнокислий однозаміще-

1. BenMeir YA, Jami E, Portnik Y, Yaacoby S, Chen Y, Ogunade IM, et al. Effect of silage inoculants on the quality of baled whole-crop wheat silages and milking cow performance. Grassland Science. 2018; 64(3):207-214.

2. Blajman JE, Vinderola G, Paez RB, Signorini ML. The role of homofermentative and heteroermentative lactic acid bacteria for alfalfa silage: a meta-analysis. The Journal of Agricultural Science. 2020; 158 (1-2):107-118.

3. Danylenko S, Teterina S, Khonkiv M. [Naukove obhruntuvannia novykh tekhnolohichnykh pryiomiv stvorennia biopreparativ dlia zahotivli sylosovanykh kormiv]. Prodovolchi resursy. 2020; 14:67-79. Ukrainian.

4. Zielińska KJ, Fabiszewska AU. Improvement of the quality of maize grain silage by a synergis- ний - 2 г/л; марганець сірчанокислий 5-водний 0,05 г/л; магній сірчанокислий 7-водний - 0,2 г/л, твін-80 - 1,0 г/л); глюкоза - 19,7 г/л; дріжджовий екстракт - 7,8 г/л; кукурудзяний екстракт - 23,6 г/л; пептон - 9,1 г/л; цитрат натрію - 6,6 г/л; ацетат натрію - 3,4 г/л. Культивування бактеріальної композиції на оптимізованому середовищі дало змогу отримати максимальний вихід біомаси, за якого показник оптичної густини становив 2,01 од., що практично вдвічі більше, ніж значення, яке було одержано при культивуванні тієї ж композиції на середовищі МРС. Було встановлено оптимальні технологічні параметри культивування бактеріальної композиції, а саме - найкращий ріст спостерігався за температури $36,4 \pm 0,4{ }^{\circ} \mathrm{C}$ за постійної підтримки значення рН в культуральному серед-

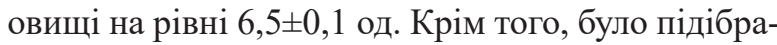
но оптимальний склад захисного середовища, яке містить цитрат натрію, сахарозу і агар, що забезпечує ступінь виживання молочнокислих бактерій 98,4\% після ліофілізації. Висновки. Новостворена бактеріальна композиція може бути використана для виробництва препаратів для силосування кукурудзи та випробувана на іншій сировині, зокрема на деяких багаторічних бобових травах (люцерна, конюшина), а умови іiі одержання можуть бути застосовані при масштабуванні технології.

Ключові слова: силос, молочнокислі бактерії, біопрепарат, оптимізація, центрально-композиційний план, поживне середовище, $\mathrm{pH}$, температура, кріопротектор.

tic action of selected lactobacilli strains. World Journal of Microbiology and Biotechnology. 2018; 34(1):1-8. doi. 10.1007/s11274-017-24009.

5. Polak-Berecka M, Wasko A, Kordowska-Wiater M, Podlesny M, Targonski Z, Kubik-Komaret A. Optimization of medium composition for enhancing growth of Lactobacillus rhamnosus PEN using response surface methodology. Pol J Microbiol. 2010; 59 (2):113-118.

6. Meena GS. Growth characteristics modeling of Lactobacillus acidophilus using RSM and ANN. Brazilian Archives of Biology and Technology. 2014; 57(1):15-22.

7. Whitlock LA, Wistuba TJ, Seifers MK, Pope RV, Bolsen KK. Effect of level of surface-spoiled silage on the nutritive value of corn silage diets. J 
Dairy Sci. 2000; 83(1):110.

8. Sychevskyi MP, Kopylova KV, Danylenko SH. [Effektivnost' preparata Senosil dlja konservirovanija silosa]. Zernovye produkty i kombikormy. 2016; 3 (63):16-21. Ukrainian.

9. Kurna€v OM. [Vplyv tekhnologiï zagotivli sinazhu na vtraty syrogo proteïnu ta iogo fraktsiinyi sklad uprodovzh zberigannya]. Kormi i kormovirobnitstvo. Mizhvidomchii tematichnii naukovii zbirnik. Vinnitsya; 2010; 66:274-280. Ukrainian.

10. Dogi CA, Pellegrino M, Poloni V, et al. Efficacy of corn silage inoculants on the fermentation quality under farm conditions and their influence on Aspergillus parasitucus, A. flavus and A. fumigatus determined by q-PCR. Food Additives \& Contaminants. Part A: 2015; 32(2):229-235.

11. Corsetti A, Gobbetti M, Rossi J, et al. Antimould activity of sourdough lactic acid bacteria: identification of a mixture of organic acids produced by Lactobacillus sanfrancisco CB1. J Appl Microbiol and Biotechnol. 1998; 50:253-256.

12. Vajsbah F. [Budushhee konservirovanija kormov]. Problemy biologii produktivnyh zhivotnyh. 2012; 2:49-70. Russian.

13. Krooneman J, Faber F, Flderkamp AC, et al. Lactobacillus diolivorans sp. now, a 1,2-propanediol - degrading bacterium isolated from aerobically stable maize silage. Front Envir Microbiol. 2002; 52:639-646.

14. Driehuis F, Oude Elferink SJ WH, Spolestra SF. Anaerobic lactic acid degradation during ensilage of whole-crop maize inoculated with Lactobacillus buchneri inhibits yeast growth and improves aerobic stability. J Appl Microbiol. 1999; 87(4):583-594.

15. Xu D, Ding W, Ke W, Li F, Zhang P, Guo X. Modulation of metabolome and bacterial community in whole crop corn silage by inoculating homofermentative Lactobacillus plantarum and heterofermentative Lactobacillus buchneri. Front Microbiol. 2019; 9:3299. doi: 10.3389/ fmicb.2018.03299

16. Shütz H, Radler F. Anaerobic reduction of glycerol to propanediol - 1,3 by L. brevis and L. buchneri. Systematic and Applied Microbiology. $1984 ; 5: 169-178$.
17. Inglis GD, Yanke LJ, Kawchuk LM, McAllister TA. The influence of bacterial inoculants on the microbial ecology of aerobic spoilage of barley silage. Can J Microbiol. 1999; 45:77-87.

18. Danner H, Holzer M, Mayrhuber E, Braun R. Acetic acid increases stability of silage under aerobic conditions. Appl Environ Microbiol. 2003; 69:562-567.

19. Pang H, Zhang M, Qin G, et al. Identification of lactic acid bacteria isolated from corn stovers. Anim Sci J. 2011; 82(5):642-53. doi: 10.1111/ j.1740-0929.2011.00894.x.

20. Kostenko VM, Panko VV, Syrovatko KM. [Praktykum z hodivli silskohospodarskykh tvaryn]. Vol I. «Khimichnyi sklad, otsinka pozhyvnosti ta yakosti kormiv». Vinnytsia: RVV VSAU; 2008. Ukrainian.

21. DSTU 7169:2010. [Kormy, kombikormy, kombikormova syrovyna. Metody vyznachannia vmistu azotu i syroho proteinu]. Ukrainian.

22. Velikaya E, Suhodol V. [Laboratornyiy praktikum po kursu obschey tehnologii brodilnyih proizvodstv (obschie metodyi kontrolya)]. 2th ed. Moskow: Legkaya i pischevaya promst. 1983. Russian.

23. DSTU 8564:2015 [Kormy dlya tvaryn, syrovyna dlya vyhotovlennya povnoratsionnykh sumishey, vydilennya tvaryn. Metody vyznachannya vmistu orhanichnykh kyslot]. Ukrainian.

24. DSTU 7643:2014. [Kormy dlya tvaryn. Metody vyznachannya amiachnoho azotu i aktyvnoyi kyslotnosti (pH)]. Animal feed. Methods for determination of ammonia nitrogen and active acidity $(\mathrm{pH})$. Ukrainian.

25. Burns P, Borgo MF, Binetti A, et al. Isolation, characterization and performance of autochthonous spray dried lactic acid bacteria in maize micro and bucket-silos. Front Microbiol. 2018; 9:1-11. doi:10.3389/fmicb.2018.02861

26. Siedler S, Balti R, Neves AR. Bioprotective mechanisms of lactic acid bacteria against fungal spoilage of food. Current opinion in biotechnology. 2019; 56:138-146. doi: 10.1016/j.copbio.2018.11.015

27. Saarisalo E, Skyttä E, Haikara A, et al. Screening and selection of lactic acid bacteria strains 
suitable for ensiling grass. J Appl Microbiol. 2007; 102: 327-336. doi: 10.1111/j.1365-2672. 2006.03103.x

28. Khonkiv M, Teterina S, Danylenko S, Potemska O. [Vykorystannia bahatokryterialnoi optymizatsii pozhyvnoho seredovyshcha dlia na- kopychennia biomasy molochnokyslykh bakterii]. Naukovi pratsi NUKhT. 2020; 26(4):46-57. Ukrainian.

29. Danylenko S. [Zberihannia kultur molochnokyslykh mikroorhanizmiv]. Naukovi pratsi NUKhT. 2015: 21(1):28-32. Ukrainian.

Received 15.03.2021 